\title{
Cell swelling and ion redistribution assessed with intrinsic optical signals*
}

\author{
OTTO W. WITTE ${ }^{1}$, HEIKE NIERMANN ${ }^{1}$ and KNUT HOLTHOFF ${ }^{2}$ \\ ${ }^{1}$ Neurologische Klinik der Heinrich Heine Universität, Moorenstr. 5, 40225 Düsseldorf, Germany \\ ${ }^{2}$ Department of Biological Sciences, Columbia University \\ 1002 Fairchild Center, New York, N.Y., USA
}

Manuscript received on February 5, 2001; accepted for publication on February 12, 2001.

\begin{abstract}
Cell volume changes are associated with alterations of intrinsic optical signals (IOS). In submerged brain slices in vitro, afferent stimulation induces an increase in light transmission. As assessed by measurement of the largely membrane impermeant ion tetramethylammonium (TMA) in the extracellular space, these IOS correlate with the extent and time course of the change of the extracellular space size. They have a high signal to noise ratio and allow measurements of IOS changes in the order of a few percent. Under conditions of reduced net $\mathrm{KCl}$ uptake (low $\mathrm{Cl}$ solution) a directed spatial buffer mechanism ( $\mathrm{K}$ syphoning) can be demonstrated in the neocortex with widening of the extracellular space in superficial layers associated with a reduced light transmission and an increase of extracellular K concentration. The nature of the IOS under pathophysiological conditions is less clear. Spreading depressions first cause an increase of light transmission, then a decrease. Such a decrease has also been observed following application of NMDA where it was associated with structural damage. Pharmacological analyses suggest that under physiological conditions changes of extracellular space size are mainly caused by astrocytic volume changes while with strong stimuli and under pathophysiological conditions also neuronal swelling occurs. With reflected light usually signals opposite to those observed with transmitted light are seen. Recording of IOS from interface slices gives very complex signals since under these conditions an increase of light transmission has been reported to be superimposed by a decrease of the signal due to mechanical lensing effects of the slice surface. Depending on the method of measurement and the exact conditions, several mechanisms may contribute to IOS. Under well defined conditions IOS are a useful supplementary tool to monitor changes of extracellular volume both in space and time.
\end{abstract}

Key words: intrinsic optic signals, spatial buffer, brain slice, extracellular space volume, spreading depression.

\section{INTRODUCTION}

The extracellular space is an important pathway for signal transmission in the brain. The properties of this pathway can be modulated by several factors causing changes of the tortuosity and the size

\footnotetext{
*Invited paper

Correspondence to: Prof. Dr. Otto W. Witte

E-mail: witteo@uni-duesseldorf.de
}

of the extracellular space. Several techniques have been developed to measure these properties. Most of these rely on the measurement of the concentration or dynamics of - ideally completely membrane impermeable - ions which are either released from a nearby microelectrode or continuously superfused over the preparation. An attractive alternative method has evolved from the observation that 
changes in extracellular space volume are accompanied by changes of the intrinsic optical properties of the preparation. In the following we will describe such methods and discuss their advantages and limitations.

Activity-dependent changes of the optical properties in excitable tissue were first described several decades ago (Hill and Keynes 1949). Such activity-dependent intrinsic optical signals were recorded from different preparations including cerebral slices (Lipton 1973, MacVicar and Hochman 1991, Holthoff and Witte 1997, Andrew and MacVicar 1994, Holthoff et al. 1994), and isolated whole brain (Federico et al. 1994). Similar signals can also be recorded in vivo in animals (Grinvald et al. 1988) and in humans (Haglund et al. 1992). Two major components of the signal in vivo can be attributed to either changes in blood volume or changes in oxygen consumption (Frostig et al. 1990) while the nature of a third component is not yet clear. This latter component is wave length-independent and based on scattered light. In vitro, only the third component of the intrinsic optical signal can be recorded. Several studies have indicated that this component is attributable to cell swelling (MacVicar and Hochman 1991, Andrew and MacVicar 1994, Andrew et al. 1999, McManus et al. 1993, Holthoff and Witte 1996).

A change of light transmission by cell swelling was first demonstrated in erythrocytes (see Aitken et al. 1999). This cell swelling does not depend on the presence of haemoglobin and can also be recorded from leukocytes and tumour cells. Shrinkage of the cells following exposure to hypertonic solutions was associated with a reduction of light transmission, and swelling with an increase. One could envisage that the alteration of light transmission is due to a change in the refractory index between intra- and extracellular compartments. However, White et al. (1996) showed that - among others - also changes in the refractive index of the membrane bilayer that result from an alteration in the extent of hydration and/or the phospholipid packing density contribute to the light scattering. Another property which may contribute is the unfolding of a cell as it swells (cf. Andrew et al. 1999).

The situation is complicated if one considers that neurons as well as glial cells may contribute to light scattering, and cellular as well as nuclear or mitochondrial membranes may participate (cf. Muller and Somjen 1998). One can thus not simply derive the light scattering from theoretical considerations. It is therefore necessary to show by actual measurements under which conditions changes of intrinsic optical signals do correlate to extracellular volume changes.

\section{TECHNICAL CONSIDERATIONS}

Intrinsic optical signals may be recorded from transmitted or reflected light. These signals give in principle the same results though with different polarity (Aitken et al. 1999): with transmitted light, the signal intensity increases when the preparation is superfused with a hypotonic solution causing cell swelling, while it decreases with absorbed light. While the transmitted light integrates the properties of the whole trans-illuminated slice, the changes in light reflectance will mainly reflect changes in the surface layers of the slice preparation. We record the signals from an illuminated slice using a dark field configuration. This collects mainly the scattered light. In this configuration the light source is also below the slice, and the recording objective above it, and the signal intensity is mainly affected by the amount of light transmitted through the slice. In consequence, this configuration also gives an increase in light signal with cell swelling and a decrease with widening of the extracellular space (Holthoff and Witte 1996). We found a higher signal-to-noise ratio using the dark-field configuration compared to transmitted light. In darkfield configuration the slice shows a rather uniform light intensity. It has not been tested whether - compared to brightfield configuration - this configuration is more sensitive to the refractive index of the membrane bilayer and less to the opacity of the cells.

Recordings are usually obtained in the near infrared range. Other than in the intact brain, the sig- 
nal is not wavelength dependent. It is therefore unlikely that absorption changes of cytochromes influence the optical signal (MacVicar and Hochman 1991). The longer wavelength is chosen because it penetrates better into the depth of the slice than does visible light, resulting in a more homogeneous background intensity distribution of the original microscopic image. It is important to remove the infrared cut-off filter of the CCD-camera which is usually mounted in front of the target.

One important issue is the choice of the camera and the optical imaging system. Even with strong stimuli like spreading depressions the change of the intrinsic optical signal is only in the order of $10 \%$, and it is much smaller with physiological stimuli and in the darkfield configuration. With an 8-bit camera which has to span the whole range from white to black with only 256 intensity levels, such small changes can only be recorded with massive averaging. One bit is furthermore lost by image subtraction. A better alternatives is the use of a scientific grade CCD camera with a signal resolution of at least 12 bit. Alternatively, contrast enhancement may be used (cf. Fig. 1). We use a two step contrast enhancement (Holthoff and Witte, 1998): The analogue signal is amplified in such a way by the camera control unit that the grey levels of interest span the complete 12 bit input of the DVS 3000 video processing unit. Within this processor, a resting image is captured before stimulation and subtracted online from the current video images. Additionally, the resulting difference images are 8-fold digitally enhanced. For that, the function called 'enhancement look-up table (LUT) processing' of the DVS 3000 is used. It allows to project a part of the dynamic range onto the full range of 0-255 pixel values of the video frame grabber in the computer.

Most experiments are carried out with slices from juvenile animals. These are much easier illuminated because they are less opaque. However, it was recently shown in our lab that it is also possible to make recordings of intrinsic optical signals of slices obtained from adult animals (Sagnak and Niermann, unpublished observations). In our hands, a vibratome causes less damage to the slice, and allows better signals than a tissue chopper.

All of our recordings were obtained from submerged slices. Intrinsic optical signals may also be recorded from interface chambers. The differences between these two configurations have elegantly been investigated by Kreisman et al. (1995) who measured light transmittance in interface and submerged slices. They reported that the sign of the intrinsic optical signals reverse when the fluid level in a tissue slice is raised so as to completely submerge the slice. Thus, superfusion of a submerged slice with hypotonic solution causing a cell swelling results in increased light transmission, while the same slice displays a decreased light transmission when brought into the interface configuration. They explained this effect in the following way. Cell swelling causes an increase of light transmission. In the interface configuration, this effect is compensated and even outnumbered by an increased "lensing" effect of the slice. Due to its swelling, the slice bulges out of the solution and its surface assumes the shape of an optical lens. Shortening of the radius of curvature increases bending of light rays and decreases the amount of light proceeding to the detector. Under these conditions, the actual size and direction of the signal may depend even on the distance between detector and slice surface.

\section{MATERIALS AND METHODS}

\section{Preparation of Cortical Brain Slices}

Experiments were done on juvenile male Wistar rats (14 days old). The animals were anesthetized and decapitated. Brains were rapidly removed and cooled to $4^{\circ} \mathrm{C}$. $400 \mu \mathrm{m}$ thick neocortical coronal slices were prepared and stored at room temperature in artificial cerebrospinal fluid (aCSF) containing (in mM): $\mathrm{NaCl} 124, \mathrm{NaHCO}_{3} 26, \mathrm{KCl}_{3}, \mathrm{CaCl}_{2}$ $2, \mathrm{MgSO}_{4} 2, \mathrm{NaH}_{2} \mathrm{PO}_{4} 1.25$, and glucose 10, equilibrated with $95 \% \mathrm{O}_{2}$ and $5 \% \mathrm{CO}_{2}$ to $\mathrm{pH}$ 7.4.

The slices were stored in the recording chamber submerged at $32^{\circ} \mathrm{C}$ and equilibrated for at least 30 min before starting with any experimental procedure. To avoid changing light reflections at the 

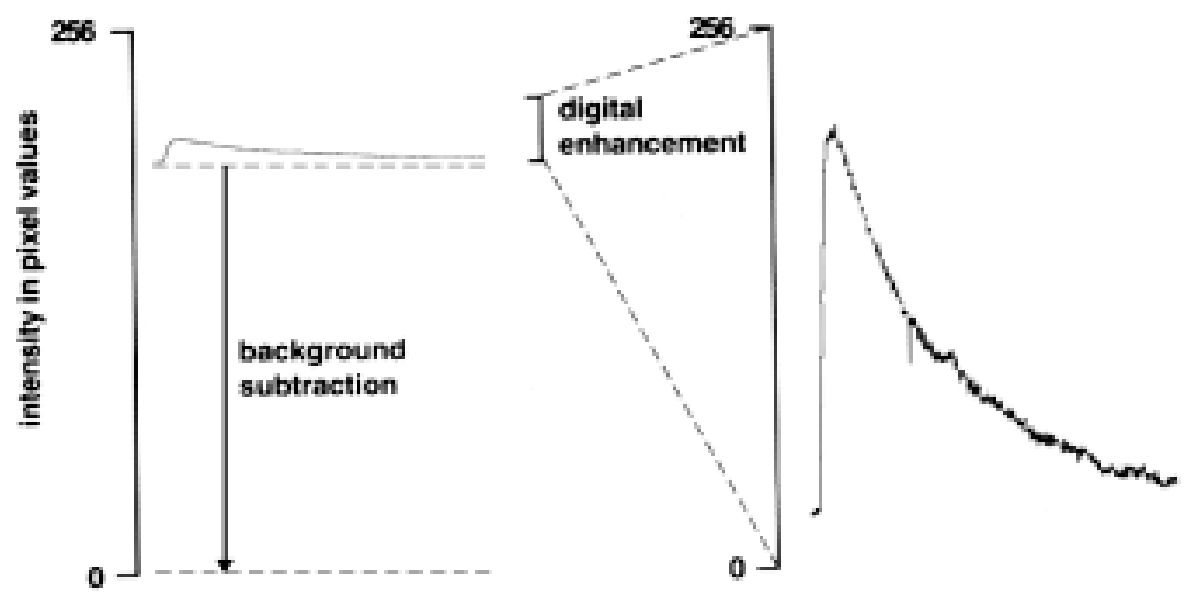

Fig. 1 - Contrast enhancement of images. In order to achieve sufficient signal dynamics the video signal is first offset corrected and analogue enhanced, and is then digitally enhanced before it is fed into a conventional 8 bit video digitizer. From Holthoff and Witte 1998, with permission.

boundary between water and air, we covered the recording chamber with a small cover slip. For electrical stimulation (pulses of $200 \mu \mathrm{s} / 2-9 \mathrm{~V}$ in a train of $50 \mathrm{~Hz}$ for $2 \mathrm{~s}$ ), a bipolar concentric stimulation electrode (SNEX 100, Science Products Inc.) was put perpendicularly into the slice in layer VI near to the border of the white matter. If the stimulation electrode was put diagonally into the slice we failed to induce IOSs due to a short circuit via the bath fluid. Therefore, the first $2 \mathrm{~mm}$ of the tip of the stimulation electrode (tip diameter $100 \mu \mathrm{m}$ ) were bent by about 90 degrees.

\section{OPTICAL IMAGING}

A schematic drawing of the experimental setup is given in Fig. 2. An upright microscope (Axioskop FS, Zeiss) with an $\times 2.5$ Neofluar objective $(0.075$ n.A.) was used. The slices were illuminated using a darkfield configuration. The illumination light was filtered with a bandpass interference filter $(750 \pm$ $50 \mathrm{~nm}$, Oriel). The video imaging system consisted of a CCD (charge coupled device) camera (C 240077 type 01, Hamamatsu), a camera control unit (CCD-camera control unit C2400, Hamamatsu) including an analogue contrast enhancement and shading correction system, a video processing device
(DVS 3000, Hamamatsu), and a S-VHS Videorecorder (RTV 950 PC, Blaupunkt). Experiments were analyzed off-line using a Macintosh FX personal computer equipped with a frame grabber card (QuickCapture, Data Translation) and the NIH Image software.

To detect stimulation-induced changes in IOSs, the video signal obtained from the CCD-camera was contrast enhanced and inhomogenities were corrected by the shading correction system. This image processing was done by the camera control unit, i.e. before digitizing the images by the DVS video processor. Usually, a double contrast enhancement was chosen. The shading correction unit includes linear and elliptic characteristic curves. With this function it was possible to correct also uneven intensities across the field of view. Image processing including background subtraction, digital enhancement of the difference image, and moving averaging were done in a DVS 3000 video processing system. Finally, a moving average filter, processing two images at a time, was applied to reduce noise.

\section{ION-SELECTIVE Microelectrodes}

Double-barreled ion-selective microelectrodes (ISMEs) were used to determine extracellular $\mathrm{K}^{+}$- 


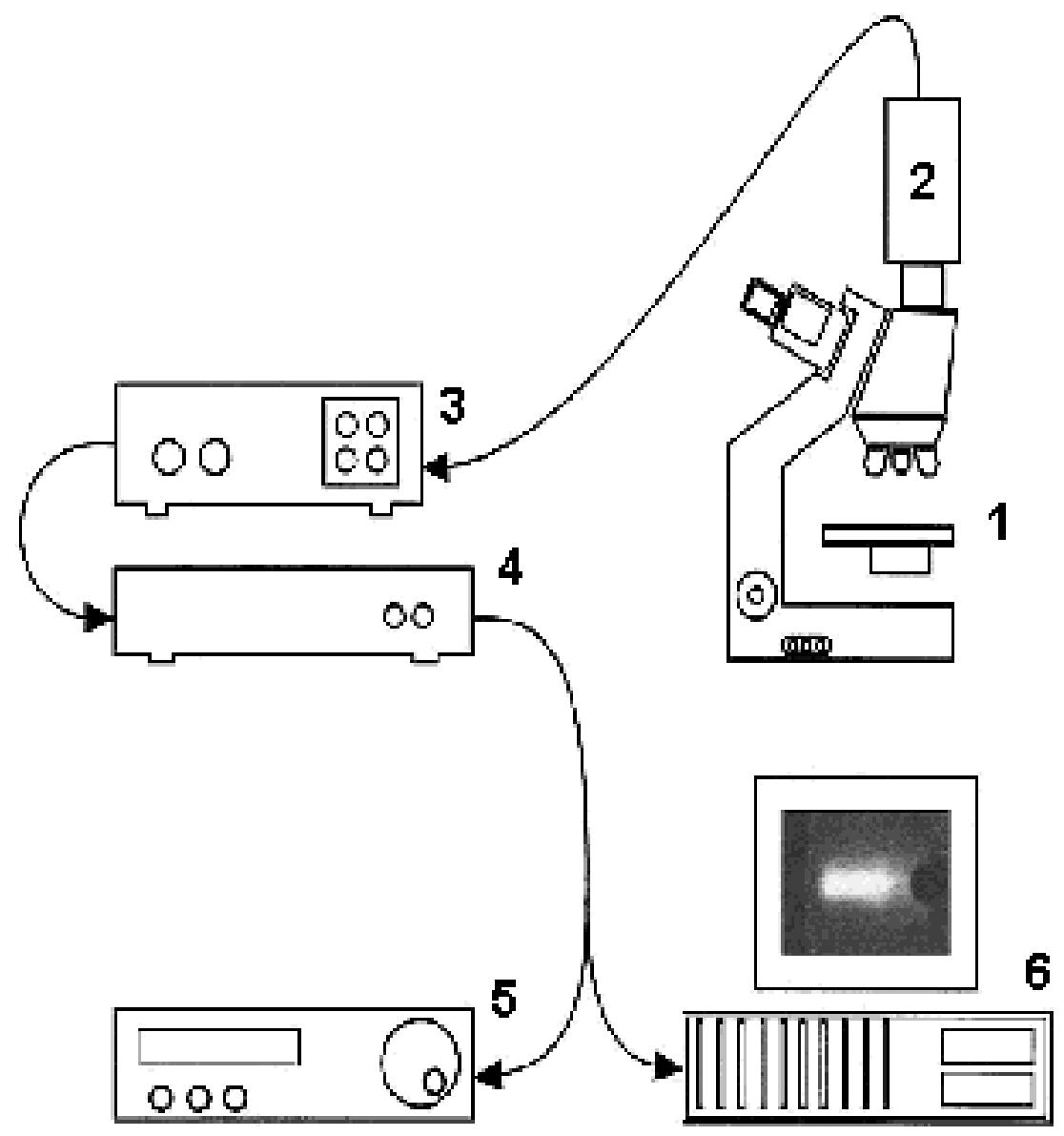

Fig. 2 - Arrangement of recording. The slices were illuminated using a darkfield configuration of an upright microscope (1). The video imaging system consisted of a CCD camera (2), a camera control unit including an analogue contrast enhancement and shading correction system (3), and a video processing device (4). Due to the previous contrast enhancement (see Fig. 1) the signal of interest spans the complete 8 bit input range of the computer (6) and can be stored on conventional S-VHS recorders (5). From Holthoff and Witte 1998, with permission.

concentration and changes of ECS volume. In these experiments ion concentrations and IOSs were recorded simultaneously. ISMEs were prepared with a liquid potassium ion exchanger (Corning 477317) and calibrated in conventional fashion. In addition to its selectivity for potassium ions, the ion exchanger is highly selective for quaternary ammonium ions (Hansen and Olsen 1980, Huang and Karwoski 1992a, Huang and Karwoski 1992b). For de- tection of changes in extracellular space volume, $10 \mathrm{mM}$ tetramethylammoniumchloride (TMACl) were added to the extracellular fluid (Ransom et al. 1985, Huang and Karwoski 1992b). To maintain ionic strength, equimolar amounts of $\mathrm{NaCl}$ were omitted. Because of its size and charge, TMAions are largely restricted to the extracellular space (Nicholson and Phillips 1981), although they may be taken up by glial cells to a steady intracellular 
level (Ballanyi et al. 1990). Changes in extracellular TMA-concentration can be interpreted as alterations in ECS volume. Relative alterations of ECS volume were calculated using the following expression (Dietzel et al. 1980):

$$
\begin{gathered}
\text { percentage of shrinkage of ECS }= \\
\left(1-\frac{\left[\mathrm{TMA}^{+}\right]_{0} \text { before activity }}{\left[\mathrm{TMA}^{+}\right]_{0} \text { after activity }}\right) \times 100
\end{gathered}
$$

In the presence of quaternary ammonium ions, the used ISMEs are virtually blind to potassium ions (Huang and Karwoski 1992b).

\section{RESULTS}

\section{STIMULATION-INDUCED INTRINSIC OPTICAL}

\section{SignALS}

Fig. 3 shows representative intrinsic optical signal from a neocortical slice following stimulation of layer VI with a $2 \mathrm{~s} 50 \mathrm{~Hz}$ train. Such a stimulation is expected to depolarize neurons by excitatory postsynaptic potentials and action potentials which are associated by outwardly directed potassium currents (Dietzel and Heinemann 1986a, Lux et al. 1986). The signal displayed a characteristic pattern with an increased light signal which had a maximum around layer IV. Using such stimulation paradigms, it is possible to functionally map the cortex, yielding characteristic activation patterns in different brain areas (Holthoff, Sagnak and Witte, unpublished observations). The activation columns were associated with increases of extracellular potassium activity from a baseline of $3 \mathrm{mM}$ up to peak levels of $10 \mathrm{mM}$ (cf. Fig. 3A). The TMA signal increased in association with the light signal indicating a reduction of extracellular space size.

The intrinsic optical signal was well reproducible in size and time course with subsequent stimulations. In the recording configuration chosen for our experiments, it had very high signal to noise ratios which were at least on order of magnitude better than the signal to noise ratio of the TMA signal. With different stimulation intensities up to $10 \mathrm{~V}$, a linear relationship between signal size and TMA signal was found.

The intrinsic optical signal correlated well with the TMA signal, both in space and time, suggesting that it mainly indicated changes of extracellular space size. There was a good correlation between the amplitude of the intrinsic optical signal and the change of the TMA signal, both in the vertical extension (from layer I to layer VI) and in the horizontal dimension (Holthoff and Witte 1998). In contrast, amplitude and extension of the intrinsic optical signals and the increases of extracellular potassium concentration did not correlate well (cf. Fig. $3 \mathrm{~A})$. The stimulation-induced intrinsic optical signals had a time to peak of $3.8 \pm 0.6 \mathrm{~s}(\mathrm{n}=20)$ very similar to that of the TMA signal $(3.1 \pm 0.3 \mathrm{~s}, \mathrm{n}=10)$ and slower than the potassium signal $(2.1 \pm 0.04 \mathrm{~s}$, $\mathrm{n}=10$ ). The potassium concentration decayed back to baseline levels from a maximum of $7.4 \pm 0.9 \mathrm{mM}$ $(\mathrm{n}=10)$ with a mono-exponential time constant of $3.1 \pm 0.6 \mathrm{~s}(\mathrm{n}=10)$ considerably faster than the intrinsic optical signal $(40 \pm 10 \mathrm{~s}, \mathrm{n}=20)$ or the TMA signal $(14 \pm 4,7 \mathrm{~s}, \mathrm{n}=10)$. The somewhat faster decay of the TMA signal can be explained by a diffusion of TMA away from the area of local increase into the surrounding bath (Hansen and Olsen 1980). In accordance with the assumption that the bright signal is caused by a net uptake of $\mathrm{KCl}$ in the cells a stimulation does not induce any bright signal in the absence of chloride in the solution (Holthoff and Witte 1996). Concomitantly, the TMA signal is also blocked while the amplitude of the extracellular potassium transient is not significantly affected. A block of the bright signal as well as the TMA signal by furosemide indicates that the swelling is probably mainly due to an uptake of $\mathrm{KCl}$ into glial cells by a furosemide-sensitive $\mathrm{Na}-\mathrm{K}-2 \mathrm{Cl}$ cotransporter (Holthoff and Witte 1996).

\section{DARK WAVES}

The brain possesses several mechanisms to control the ensuing extracellular accumulation of potassium: a $\mathrm{Na} / \mathrm{K}$-exchanger is present in glial cells and neurons, and a $\mathrm{NaK} 2 \mathrm{Cl}$-cotransporter resulting in a 

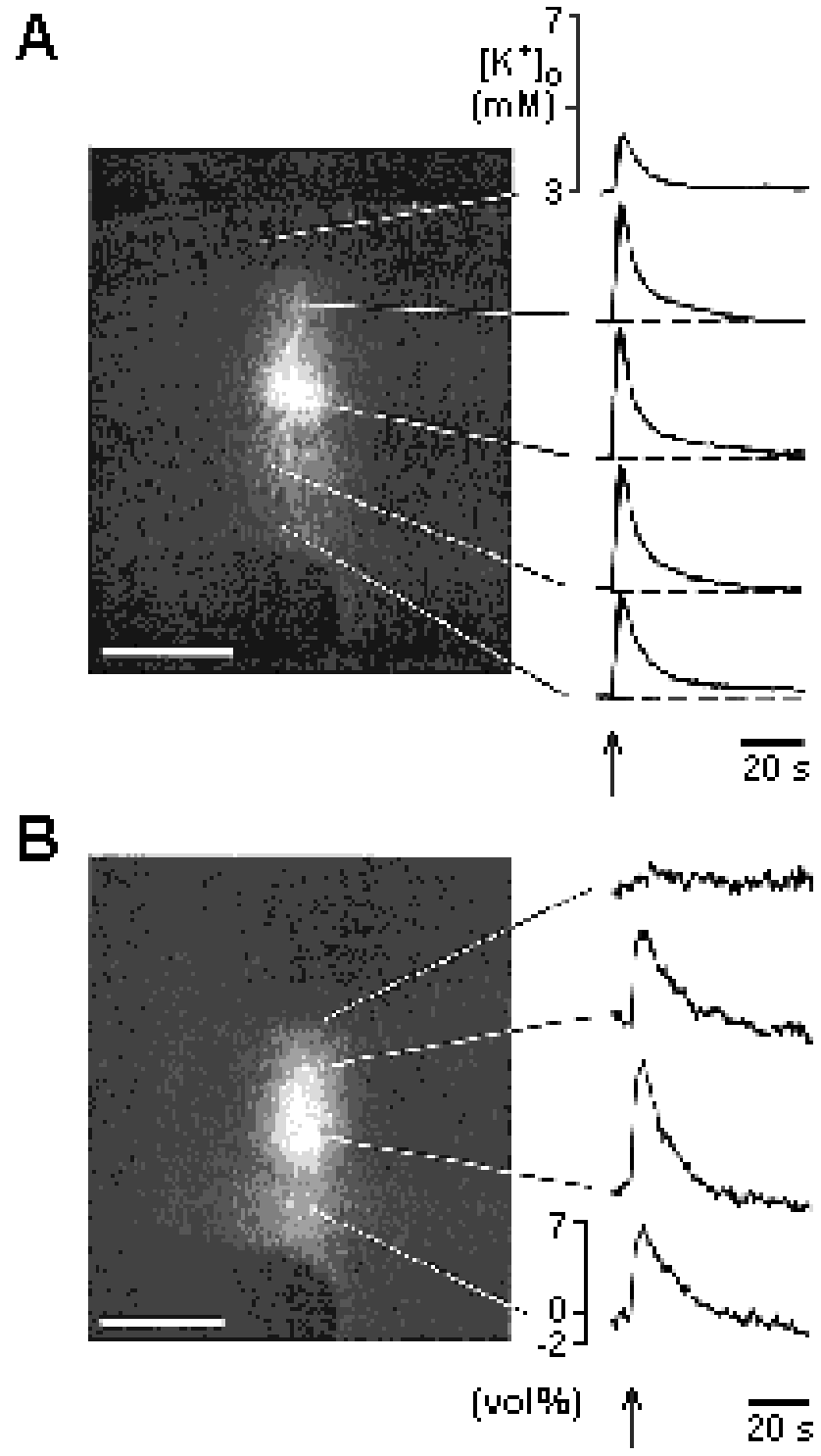

Fig. 3 - Correlation between intensity of intrinsic optical signal and changes in extracellular potassium concentration and extracellular space volume. A. Intrinsic optical signal from neocortex $4 \mathrm{~s}$ after onset of stimulation ( $2 \mathrm{~s}$ train) in layer VI and time course of extracellular potassium concentrations in different cortical layers. Scale bar $300 \mu \mathrm{m}$. The dotted lines represent an extracellular potassium concentration of $3 \mathrm{mM}$. The arrow marks the beginning of stimulation. B. Intrinsic optical signal $4 \mathrm{~s}$ after beginning of stimulation and time course of shrinkage of the extracellular space volume in different cortical layers as assessed by measurement of TMA concentration. Scale bar $300 \mu \mathrm{m}$. The arrow marks the beginning of stimulation.

net-uptake of $\mathrm{KCl}$ is present in glial cells (Walz and Hinks 1986). In addition, a so-called spatial buffer mechanism may contribute to potassium homeosta- sis (Orkand et al. 1966, Dietzel et al. 1980, Dietzel et al. 1982, Dietzel et al. 1989, Dietzel and Heinemann 1986b, Gardner-Medwin and Nicholson 1983, 


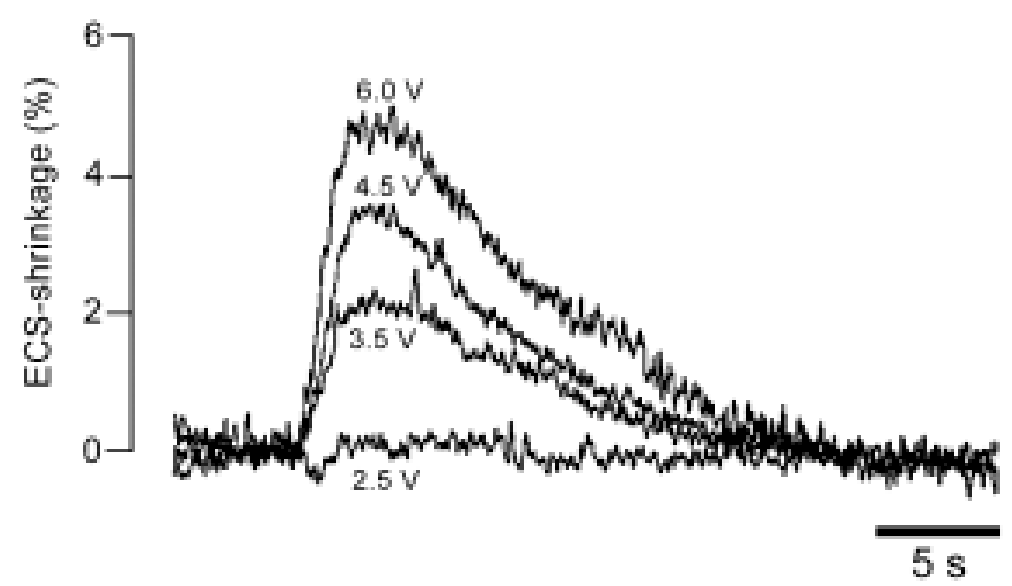

Fig. 4 - Time course of stimulation-induced changes of intrinsic optical signals in layers II/III, induced by subsequent stimulations in layer VI with different stimulation strengths.

Gardner-Medwin 1986). The glial cells are coupled by gap junctions constituting a syncytium. This network may work as a draining system for extracellular potassium, which takes potassium up in regions of high potassium and liberates it in low potassium regions. In mammalian retina, a directional preference of the spatial buffer has been described, extending the concept to "potassium siphoning" (Newman et al. 1984).

A working spatial buffer mechanism should lead to characteristic alterations of the extracellular space. The extracellular space should shrink at regions of potassium uptake and should widen at regions where potassium is liberated. In terms of changes of intrinsic optical signals this should be reflected in a darkening of the slice. In order to visualize such a mechanism we lowered the extracellular chloride concentration to $17 \mathrm{mM}$ (Holthoff and Witte, 2000). This should increase the relative contribution of the spatial buffer mechanism to ion homeostasis compared to net local cellular $\mathrm{KCl}$ uptake.

Electrical stimulation in layer VI caused a bright intrinsic optical signal in middle cortical layers. In contrast, superficial and lower cortical layers became darker (Fig 5). The brightening was caused by shrinkage of the extracellular space as shown by measurement of TMA concentration. In layer I, extracellular space volume increased by $1.9 \pm 0.2 \%(\mathrm{n}=4$, mean \pm SD). The darkening of the slice in cortical layers I-III started perpendicular above the stimulation electrode and in the next seconds spread out parallel to cortical layer orientation to a full width half maximum of $910 \pm 300 \mu \mathrm{m}$ $(n=9)$. These results confirm the predictions of a spatial buffer mechanism. Also in accordance with these predictions the extracellular potassium concentration increased in all cortical layers, also in the region with the dark signal.

Gap junctional communication between glial cells is an important part of the functioning of the spatial buffer mechanism. We therefore tested whether stimulation-induced changes of the extracellular space were altered by modulation of the functional coupling between cells. Carbenoxolone and intracellular acidification which block gap junctions were tested (Ishimatsu and Williams 1996). Treatment of the slices with carbenoxolone as well as intracellular acidification effectively blocked stimulation-induced widening of the extracellular space in superficial cortical layers (Holthoff and Witte, 2000). These procedures did not alter field 


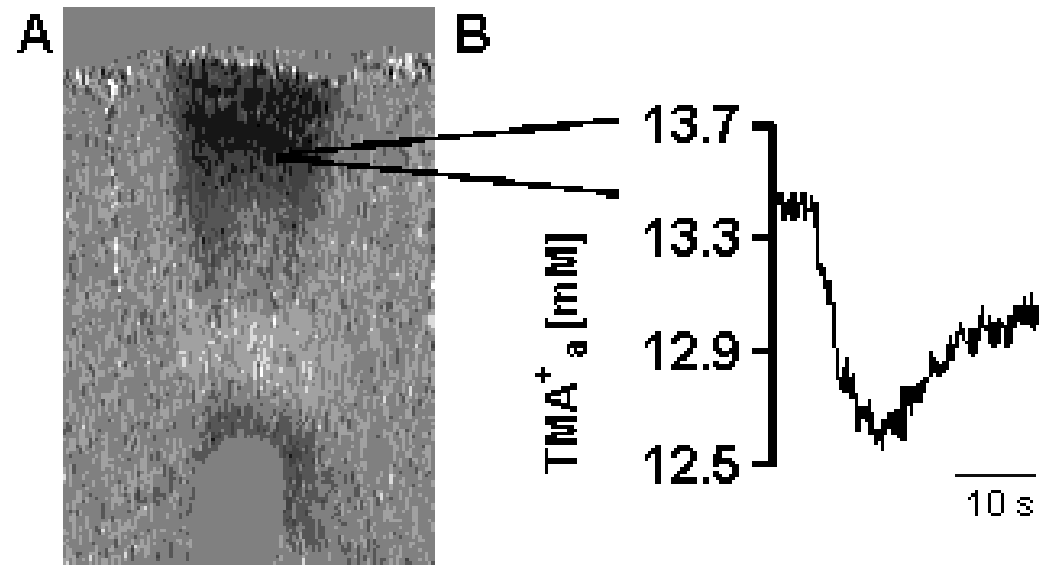

Fig. 5 - Reduced light transmission associated with widening of the extracellular space in superficial cortical layers. Recordings were obtained under conditions which reduce net $\mathrm{KCl}$ uptake (low chloride solution) and enhance the contribution of the spatial buffer mechanism to clearance of potassium from the extracellular space. Signal induced by stimulation in layer VI of the cortex.

potential amplitudes suggesting that excitability was not influenced.

It has recently been demonstrated that astrocytes express high levels of a water channel, aquaporin-4. Since vasopressin is known to regulate aquaporin expression and translocation in kidney collecting ducts, and thereby control water reabsorption, we hypothesized that vasopressin might serve a similar function in the brain. By recording intrinsic optical signals in an acute cortical slice preparation we showed that the radial water flux in the neocortex which manifests itself as a black wave are facilitated by vasopressin and vasopressin receptor V1a agonists. V1a antagonists blocked the facilitatory effect of vasopressin and reduced the water flux even in the absence of any exogenous agonist. V2 agonists or antagonists had no effect. These data suggest that vasopressin and V1a receptors play a crucial role in the regulation of brain water and ion homeostasis, most probably by modulating aquaporin-mediated water flux through astrocyte plasma membranes (Niermann et al. 2001).

All the above experiments were carried out within the more or less physiological ranges of activity, and with changes of the extracellular space in the order of a few percent. Under these conditions, there is a very good correlation between changes of extracellular space size and intrinsic optical signal. There have, however, been recent reports that under pathophysiological conditions this relationship might be lost (Muller and Somjen 1998, Vargova et al. 1999, Tao and Nicholson 1999). Conditions that are expected to cause massive changes of cell size include elevations of potassium above the ceiling level of about 10-15mM (Heinemann and Lux 1977), spreading depressions, ischemia, and pronounced changes of the osmolarity of the cerebrospinal fluid. Fig. 6 shows a recording of a spreading depression from the neocortex in our setup. The signal starts as a wave with a bright signal, which slowly moves across the slice and is followed by a dark signal.

\section{DISCUSSION}

The present data show that with physiological activity in the brain slice preparation intrinsic optical signals (transmitted light, darkfield configuration, contrast enhancement, submerged slice) are well correlated to changes of extracellular space volume, and 

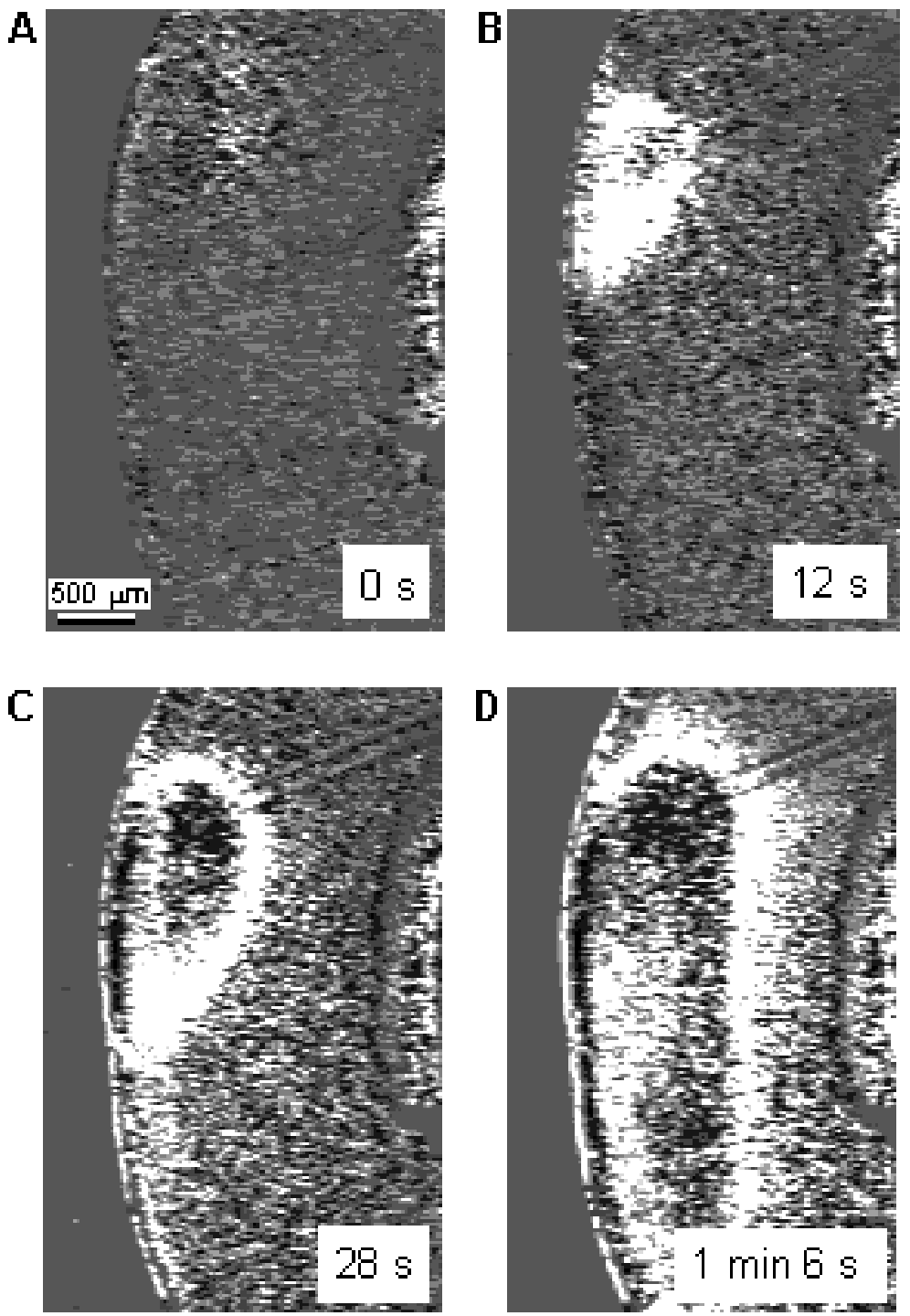

Fig. 6 - Subsequent appearance of increase and decrease of light transmission with spreading depression in the neocortex. Spreading depression induced by local application of $2 \mathrm{M} \mathrm{KCl}$ through microelectrode.

hence cell swelling and shrinkage. Spatial extent, time course, alteration by low chloride solution and furosemide, as well as direction of the signal all behave in the expected ways, and the intrinsic optical signals can be employed to demonstrate also increases of extracellular space size as expected from the spatial buffer mechanism. The signal has an ex- cellent signal to noise ratio in the employed setup, is well reproducible, and shows a fast time resolution sufficient to monitor changes of extracellular space size in the order of seconds.

As an independent means to measure changes of extracellular space size, we superfused the slices with tetramethylammonium or choline (not shown) 
which within the time frame of the measured signals are largely restricted to the extracellular space. The major limitation of this technique is a diffusion artefact that occurs during slow focal changes in the extracellular space size. The alternative technique is the diffusion analysis as introduced by C. Nicholson (Nicholson 1985, Lehmenkuhler et al. 1993, Nicholson 1999). This technique in addition allows to calculate the tortuosity and the volume fraction of the extracellular space. Unfortunately, the time resolution of this technique is much to slow too monitor the changes of extracellular volume following afferent stimulation as shown in this paper. This method might even be too slow to measure the regulatory volume decrease which is to a large extend mediated through astrocytic volume-sensitive organic anion channels. These anion channels activate within a few seconds following exposure to an osmotic stress (Basarsky et al. 1999)

The present data favour the glial cells as the major cell type involved in regulation of extracellular volume under physiological conditions. Thus the widening of the extracellular space in superficial cortical layers depends on cell coupling as shown by pharmacological manipulations and are suggested to be due to potassium syphoning through the glial network. The local decreases of extracellular volume can be blocked by furosemide, suggesting an uptake of $\mathrm{KCl}$ by the glial furosemide-sensitive $\mathrm{Na}-\mathrm{K}$ 2Cl cotransporter (Walz and Hinks 1986, Walz and Hinks 1985, Walz and Hertz 1984). Under more extreme conditions, the situation changes: in the hippocampus, spreading depressions first cause a bright signal in the dendritic layers, followed later by a bright signal in the cell soma layer (Basarsky et al. 1998, Andrew et al. 1999, Jarvis et al. 1999, Rutledge et al. 1998). Under these conditions cell swellings may also occur in the absence of chloride in the bath fluid, possibly due to a cellular uptake of glutamate and other organic anions (Muller and Somjen 1998).

The nature of the black wave following spreading depressions or application of NMDA (Jarvis et al. 1999) is unclear. As shown in this paper, one can record black waves which are accompanied by increases of extracellular volume under certain conditions. Polischuk et al. (Polischuk et al. 1998) have shown that a darkening of the signal can also be observed when irreversible neuronal damage occurs. Further experiments will be necessary to analyse those conditions in which discrepancies occur between intrinsic optical signal and changes of extracellular space size.

\section{RESUMO}

Mudanças do volume celular estão associadas com alterações de sinais ópticos intrínsecos (SOI), que são revistos no presente trabalho. Em fatias do encéfalo submersas in vitro, a estimulação aferente induz um aumento na transmissão de luz. Segundo avaliado por medidas no espaço extra-celular do ion tetra-metil-amônio (TMA), que pouco permeia a membrana, estes SOI se correlacionam com a extensão e curso temporal das mudanças na dimensão do espaço extra-celular. SOI têm uma alta relação sinal: ruído e permitem medidas de (suas) mudanças da ordem de alguns percentis, com velocidade de video. Sob condições de reduzida captação líquida de $\mathrm{KCl}$ (solução com baixo cloreto), um mecanismo de tamponamento espacial dirigido (sifonamento de potássio) pode ser demonstrado no neocórtex, com ampliação do espaço extra-celular nas camadas superficiais, associada com reduzida transmissão de luz e um acréscimo da concentração de potássio extra-celular. A natureza dos SOI sob condições fisiopatológicas é menos clara. Depressões alastrantes causam inicialmente um acréscimo na transmissão de luz e depois um decréscimo. Tal decréscimo tem sido observado após aplicação de NMDA onde está associado com dano estrutural. Análises farmacológicas sugerem que sob condições fisiológicas mudanças na dimensão do espaço extra-celular são causadas principalmente por mudanças no volume astrocitário enquanto que com estímulos fortes e sob condições fisiopatológicas também ocorre intumescência de neurônios. Com luz refletida são vistos usualmente sinais opostos a aqueles observados com luz transmitida. Registros de SOI da interface de fatias produzem sinais muito complexos desde que, sob estas condições, foi relatado um acréscimo de transmissão de luz ao qual se superpõe um decréscimo do sinal decor- 
rente de efeitos mecânicos de "lente" da superfície da fatia. Dependendo do método de medida e das condições exatas, vários mecanismos podem contribuir para os SOI. Sob condições bem definidas, SOI constituem uma ferramenta suplementar útil para monitorar mudanças espaciais ou temporais no volume do espaço extra-celular.

Palavras-chave: sinais ópticos intrínsecos, tamponamento espacial, fatias encefálicas, espaço extracelular, depressão alastrante.

\section{REFERENCES}

Aitken PG, Fayuk D, Somjen GG and Turner DA. 1999. Use of intrinsic optical signals to monitor physiological changes in brain tissue slices. Methods 18: 91-103.

ANDREW RD AND MACVicAR BA. 1994. Imaging cell volume changes and neuronal excitation in the hippocampal slice. Neuroscience 62: 371-383.

Andrew RD, Jarvis CR And Obeidat AS. 1999. Potential sources of intrinsic optical signals imaged in live brain slices. Methods 18: 185-196.

Ballanyi K, Grafe P, Serve G and Schlue WR. 1990. Electrophysiological measurements of volume changes in leech neuropile glial cells. Glia 3: $151-158$.

BASARSKy TA, DufFy SN, ANDREw RD AND MacVicAR BA. 1998. Imaging spreading depression and associated intracellular calcium waves in brain slices. $\mathrm{J}$ Neurosci 18: 7189-7199.

Basarsky TA, Feighan D And MacVicar BA. 1999 Glutamate release through volume-activated channels during spreading depression. J Neurosci 19: 6439-6445.

Dietzel I and Heinemann U. 1986a. Dynamic variations of the brain cell microenvironment in relation to neuronal hyperactivity. Ann NY Acad. Sci 481: 72-86.

Dietzel I And Heinemann U. 1986b. Dynamic variations of the brain cell microenvironment in relation to neuronal hyperactivity. Ann N Y Acad Sci 481: 72-86.

Dietzel I, Heinemann U, Hofmeier G and Lux HD.
1980. Transient changes in the size of the extracellular space in the sensorimotor cortex of cats in relation to stimulus-induced changes in potassium concentration. Exp Brain Res 40: 432-439.

Dietzel I, Heinemann U, Hofmeier G and Lux HD. 1982. Stimulus-induced changes in extracellular $\mathrm{Na}^{+}$and $\mathrm{Cl}^{-}$concentration in relation to changes in the size of the extracellular space. Exp Brain Res 46: 73-84.

Dietzel I, Heinemann U and Lux HD. 1989. Relations between slow extracellular potential changes, glial potassium buffering, and electrolyte and cellular volume changes during neuronal hyperactivity in cat brain. Glia 2: 25-44

Federico P, Borg SG, Salkauskus AG and MacVicar BA. 1994. Mapping patterns of neuronal activity and seizure propagation by imaging intrinsic optical signals in the isolated whole brain of the guinea-pig. Neuroscience 58: 461-480.

Frostig RD, Lieke EE, TS'O DY And Grinvald A. 1990. Cortical functional architecture and local coupling between neuronal activity and the microcirculation revealed by in vivo high-resolution optical imaging of intrinsic signals. Proc Natl Acad Sci USA 87: 6082-6086.

GARDNER-MEdwin AR. 1986. A new framework for assessment of potassium-buffering mechanisms. Ann N Y Acad Sci 481: 287-302.

Gardner-Medwin AR AND Nicholson C. 1983. Changes of extracellular potassium activity induced by electric current through brain tissue in the rat. $\mathrm{J}$ Physiol Lond 335: 375-392

Grinvald A, Frostig RD, Lieke E and Hildesheim R. 1988. Optical imaging of neuronal activity. Physiol Rev 68: 1285-1366.

Haglund MM, OJEmann GA ANd Hochman DW. 1992. Optical imaging of epileptiform and functional activity in human cerebral cortex. Nature 358: 668-671.

Hansen AJ And Olsen CE. 1980. Brain extracellular space during spreading depression and ischemia. Acta Physiol Scand 108: 355-365.

Heinemann U and Lux HD. 1977. Ceiling of stimulus induced rises in extracellular potassium concentra- 
tion in the cerebral cortex of cat. Brain Res 120: 231-249.

HiLl DK AND Keynes RD. 1949. Opacity changes in stimulated nerve. J Physiol (Lond) 108: 278-281.

Holthoff K, Dodt HU And Witte OW. 1994. Changes in intrinsic optical signal of rat neocortical slices following afferent stimulation. Neurosci Lett 180: 227-230.

HolthofF K And Witte OW. 1996. Intrinsic optical signals in rat neocortical slices measured with nearinfrared dark-field microscopy reveal changes in extracellular space. J Neurosci 16: 2740-2749.

Holthoff K And Witte OW. 1997. Recording of neuronal network properties with near-infrared darkfield microscopy. Biochimica Acta 42: 3241-3246.

Holthoff K And Witte OW. 1998. Intrinsic optical signals in vitro: a tool to measure alterations in extracellular space with two-dimensional resolution. Brain Res Bull 47: 649-655.

Holthoff K and Witte OW. 2000. Directed spatial potassium redistribution in rat neocortex. Glia 29: 288-292.

Huang B And Karwoski CJ. 1992a. Light-evoked expansion of subretinal space volume in the retina of the frog. J Neurosci 12: 4243-4252.

HuANG B AND Karwoski CJ. 1992b. Light-evoked expansion of subretinal space volume in the retina of the frog. J Neurosci 12: 4243-4252.

Ishimatsu M AND Williams JT. 1996. Synchronous activity in locus coeruleus results from dendritic interactions in pericoerulear regions. J Neurosci 16: 5196-5204.

JARVis CR, LiLge L, Vipond GJ AND ANDREw RD. 1999. Interpretation of intrinsic optical signals and calcein fluorescence during acute excitotoxic insult in the hippocampal slice [In Process Citation]. Neuroimage 10: 357-372.

Kreisman NR, LaManna JC, Liao SC, Yeh ER and AlCALA JR. 1995. Light transmittance as an index of cell volume in hippocampal slices: optical differences of interfaced and submerged positions. Brain Res 693: 179-186.
Lehmenkuhler A, Sykova E, Svoboda J, Zilles K AND Nicholson C. 1993. Extracellular space parameters in the rat neocortex and subcortical white matter during postnatal development determined by diffusion analysis. Neuroscience 55: 339-351.

LiPTON P. 1973. Effects of membrane depolarization on light scattering by cerebral cortical slices. J Physiol (Lond) 231: 365-383.

Lux HD, Heinemann U and Dietzel I. 1986. Ionic changes and alterations in the size of the extracellular space during epileptic activity. Adv Neurol 44: 619-39.

MacVicar BA And Hochman D. 1991. Imaging of synaptically evoked intrinsic optical signals in hippocampal slices. J Neurosci 11: 1458-1469.

McManus M, Fischbarg J, Sun A, Hebert S and STRANGE K. 1993. Laser light-scattering system for studying cell volume regulation and membrane transport processes. Am J Physiol 265: C562-C570.

Muller M AND Somjen GG. 1998. Inhibition of major cationic inward currents prevents spreading depression-like hypoxic depolarization in rat hippocampal tissue slices. Brain Res 812: 1-13.

Newman EA, Frambach DA and Odette LL. 1984. Control of extracellular potassium levels by retinal glial cell $\mathrm{K}^{+}$siphoning. Science 225: 1174-1175.

Nicholson C. 1985. Diffusion from an injected volume of a substance in brain tissue with arbitrary volume fraction and tortuosity. Brain Res 333: 325-329.

Nicholson C. 1999. Signals that go with the flow. Trends Neurosci 22: 143-145.

Nicholson C and Phillips JM. 1981. Ion diffusion modified by tortuosity and volume fraction in the extracellular microenvironment of the rat cerebellum. J Physiol (Lond) 321: 225-257.

Niermann H, Amiry-Moghaddam M, Holthoff K, Witte OW, Ottersen OP. 2001. A novel role of vasopressin in the brain: modulation of activity dependent water flux in the neocortex. J Neurosci 21: 3045-3051.

Orkand RK, Nicholls JG ANd Kuffler SW. 1966. Effect of nerve impulses on the membrane potential of 
glial cells in the central nervous system of amphibia. J Neurophysiol 29: 788-806.

Polischuk TM, JaRvis CR AND ANDRew RD. 1998. Intrinsic optical signaling denoting neuronal damage in response to acute excitotoxic insult by domoic acid in the hippocampal slice. Neurobiol Dis 4: 423-437.

Ransom BR, Yamate CL and Connors BW. 1985. Activity-dependent shrinkage of extracellular space in rat optic nerve: a developmental study. J Neurosci 5: $532-535$.

Rutledge EM, Aschner M ANd Kimelberg HK. 1998. Pharmacological characterization of swelling-induced $\mathrm{D}$-[3H]aspartate release from primary astrocyte cultures. Am J Physiol 274: C1511-C1520.

TAO L AND Nicholson C. 1999. Light scattering measured in brain slices with a new photon counting fiber optic system. Soc Neurosci Abstr 25: 743 (\#293.16).
Vargova L, Prokopova A, Chvatal A and Sykova E. 1999. Are the changes in intrinsic optical signals a tool to measure changes in extracellular space volume? Soc Neurosci Abstr 25: 741 (\#293.7).

Walz W and Hertz L. 1984. Intense furosemidesensitive potassium accumulation in astrocytes in the presence of pathologically high extracellular potassium levels. J Cerebr Blood F Met 4: 301-304.

Walz W and Hinks EC. 1985. Carrier-mediated KCl accumulation accompanied by water movements is involved in the control of physiological $\mathrm{K}^{+}$levels by astrocytes. Brain Res 343: 44-51.

Walz W and Hinks EC. 1986. A transmembrane sodium cycle in astrocytes. Brain Res 368: 226-232.

White G, Pencer J, Nickel BG, Wood JM and HalLETT FR. 1996. Optical changes in unilamellar vesicles experiencing osmotic stress. Biophys J 71: 2701-2715. 